The Agriculturists 18(1):103-115(2020) ISSN 2304-7321 (Online), ISSN 1729-5211 (Print)

A Scientific Journal of Krishi Foundation

Indexed Journal

DOI: https://doi.org/10.3329/agric.v18i1.49463

\title{
Isolation, Structural and Functional Characterization of Jackfruit (Artocarpus heterophyllus Lam) Seed Proteins
}

\author{
Fatema Akter $^{1}$, M. Amdadul Haque ${ }^{1 *}$, M. Abdul Baqui ${ }^{2}$ \\ ${ }^{I}$ Department of Agro-processing, Bangabandhu Sheikh Mujibur Rahman Agricultural University \\ (BSMRAU), Gazipur1706, Bangladesh; ${ }^{2}$ School of Physics, Uttara University, Dhaka 1230, \\ Bangladesh
}

*Corresponding author and Email: mahaque@bsmrau.edu.bd

Received: 09 April 2020

Accepted: 25 June 2020

\begin{abstract}
With increasing health awareness, the demand for concentrated proteins from plant sources has been rising for direct consumption or to use as an ingredient in food formulation. The characteristic information of any component is prerequisite for its efficient usage in food preparation. This study was undertaken to isolate the protein from jackfruit seeds and characterizing the physicochemical and functional properties of the isolated protein. The protein fraction from jackfruit seed flour was isolated using $\mathrm{pH}$ treatments and centrifugation process. The isolated protein was converted into powder form by a vacuum drying and grinding method. Total protein content in the isolate was determined by the Kjeldahl method. The functional properties such as solubility and gelling capacity and secondary structural elements of jackfruit seed protein isolate (JSPI) were studied. The crude JSPI contained $76.89 \%$ protein with $58.44 \%$ solubility in aquatic solvent. The conformational study by Fouriertransform infrared spectroscopy (FTIR) indicated that the $\beta$-sheet is the dominant secondary structure of JSPI that contained $50.28 \% \beta$-sheet, $21.71 \%$ a -helix, $8.86 \% \beta$-turn, and $19.15 \%$ unordered structure. The least gelation concentration of JSPI dissolved in $1.0 \mathrm{M} \mathrm{NaCl}$ solution was $12 \%$. The $\mathrm{pH}$ of the solvent significantly affected the emulsifying and foaming properties $(p<0.05)$. Based on the observed structural and functional features, JSPI has prospects to be used as a supplementary ingredient in future food formulations.
\end{abstract}

Keywords: Protein isolate, functional properties, emulsion capacity, gelling ability, vacuum dryer and protein conformation

\section{Introduction}

Protein is one of the most abundant components, which take part in constituting every cell in the living being. About $65 \%$ of the total demand for protein is being met from animal sources, whereas 35\% is from plant sources (Pasiakos et al., 2015). However, the demand for plantderived proteins is continuously increasing due to their health benefits, easy digestibility, and economic rationales (Houde et al., 2018). Isolation and functional characterization of cereal and bean proteins such as wheat, flaxseed, and lentil protein have received worthwhile attention by the researchers (Idris et al., 2003; Kaushik et al., 2016; Joshi et al., 2011). Nevertheless, in most of the cases, isolation of those proteins and their possible usage in new 
food formulations can add a little nutritional benefit. Because the majority portion of those cereals and beans may be consumed as the original form with minimal processing. Therefore, searching for proteins from low-cost and underutilized sources, their isolation and characterization with a view to utilizing them in new food formulations able to harvest maximum benefits with respect to economic and environmental aspects. The jackfruit seed is a strong alternate for this purpose. Jackfruit seeds (JFSs) consist around 10 to $15 \%$ of the total fruit weight, having starch and protein content of $79.34 \%$ and $13.50 \%$ respectively, on a dry basis (Ocloo et al., 2010).

This fruit grows abundantly in Southeast Asian countries such as Indonesia, Burma, and India as well as in some areas of Brazil, and Queensland of Australia. Jackfruit is the national fruit of Bangladesh that produces nearly one million tons in a year (BBS, 2015). A jackfruit may contain up to 500 juicy cells enclosing a seed each of them. The juicy flesh is the edible part of the fruit. A good portion of the seeds is discarded in the environment as social tradition, although a portion is consumed after minimal processing like roasting and boiling. These seeds can, however, be used as a good source of proteins, if processed suitably. Considering 14\% of the total weight of jackfruit is made up of seeds, a share 140 thousand metric tons JFS are underutilized in Bangladesh. Moreover, a considerable amount of seeds is damaged due to the lack of proper storage costing a huge national loss every year. This loss can be overcome by using the ingredients of JFS in selected food products, such as cakes and biscuits (Hasan et al., 2010).

Prior information regarding structural and functional properties of isolated proteins helps to use them with minimum capital investment in the new food formulation. For better application as an ingredient, the proteins should ideally possess several desirable functional properties such as solubility, water holding capacity, gelation, and foaming capacity. These functional properties influence the contribution of proteins in food characters during processing, storage, and consumption (Kinsella, 1979). For example, the solubility of a protein determines the digestibility of the protein enriched foods. This characteristic property (solubility) not only enhances the digestive efficiency of protein but also positively influences other features such as foaming and emulsion ability (Mcwatters and Cherry, 1977). Knowledge of the emulsifying and foaming properties of proteins is necessary to evaluate their potential to use as food additives. Several molecular parameters such as $\mathrm{pH}$, ionic strength, and viscosity are essential determinants in the formation, stability, and textural properties of protein-fat-water emulsions (Zayas and Lin, 1989). The secondary structures of a protein play an essential role in protein folding and unfolding processes. The 3D structure of the protein, which is vital for protein functionality, is attributed to compact and stable secondary structural elements such as a-helix, $\beta$-sheet, and $\beta$-turn. They are also crucial in determining evolution, size, and geometry of protein ( $\mathrm{Ji}$ and $\mathrm{Li}, 2010$ ). Fourier Transform Infrared (FTIR) spectroscopy provides information about the secondary structure of proteins by chemical composition and physical state of the whole sample (Haque et al., 2014).

Although few researchers already studied some functional properties of jackfruit seed protein (Ulloa et al., 2017; Reis et al., 2016), these are not quite sufficient to suggest the pros and cons while intending to use this protein in food preparation. More investigations on the structural and functional properties of JSPI are required to incorporate this protein in future food formulation. Besides, such information of protein from Bangladeshi varieties of jackfruit seed is nearly zero in the literature.

Therefore, the current study was designed, firstly, to find an appropriate method for isolation of JFS proteins. Secondly, to analyze the isolated protein for different functional attributes. The protein was also analyzed by infrared spectroscopy to determine its secondary structural properties. 


\section{Materials and Methods}

\subsection{Raw materials}

Jackfruit seeds were collected from the local market of Narsingdi, Bangladesh. They were sun-dried and the white outer layers of the seeds were separated. After cutting approximately $3 \times 4$ $\mathrm{mm}$ sized pieces, they were dried by Cabinet dryer at temperature $40{ }^{\circ} \mathrm{C}$ to bring the moisture content $10-12 \%$. Finally, the seeds were ground to make JFS flour and passed through a sieve (mesh no 75). The obtained powder was packed airtight into containers for further uses.

\subsection{Preparation of jackfruit Seed Protein Isolate (JSPI)}

JSPI was prepared following the protocols of (Wang et al., 1999; Idris et al., 2003) with slight modification. The seed flour was suspended in distilled water $(1: 10 \mathrm{w} / \mathrm{v})$. The $\mathrm{pH}$ of the slurry was adjusted to 9.0 using $1 \mathrm{M} \mathrm{NaOH}$ solution and kept in rest for one hour. The slurry was then centrifuged (at $12,600 \mathrm{~g}$, for $15 \mathrm{~min}$ ). The supernatant protein solution was separated and adjusted to $\mathrm{pH} 4.5$ using $1 \mathrm{M} \mathrm{HCl}$. The solution was then stirred for $30 \mathrm{~min}$ and left undisturbed for cold precipitation overnight $\left(4{ }^{0} \mathrm{C}\right)$. The supernatant was carefully siphoned off, and the obtained protein precipitate was collected by centrifugation at $2217 \mathrm{~g}$ for $15 \mathrm{~min}$. The accumulated protein was washed 3-4 times with distilled water to eliminate all soluble components. The final protein was poured into a clean tray and dried in vacuum dryer at $60{ }^{\circ} \mathrm{C}$ temperature and $85 \mathrm{kPa}$ pressure for $48 \mathrm{~h}$. The dried protein was collected and subsequently pulverized into a fine powder (JSPI) by using a grinder and sieved through sieve (mesh no 75 . The resultant powder was vacuumed sealed in high-density polythene package for further use.

\subsection{Determination of protein content}

The protein content of JSPI was determined by the Kjeldahl method (AOAC, 2005). The value of 6.25 was used as a protein conversion factor. One (1) $g$ of protein powder was used for digestion, distillation, and titration following the standard protocols for Kjeldahl method. The average values from the replicated experiments were accepted.

\subsection{Determination of functional properties of JSPI}

2.4.1 Protein solubility

The solubility of JSPI was determined according to the method used by (Beuchat et al., 1975) with slight modification. One (1) $g$ of JSPI powder was diluted into $100 \mathrm{~mL}$ of distilled water. The suspension was mixed evenly through continuous stirring for $30 \mathrm{~min}$. The suspension was then kept in the refrigerator $\left(4{ }^{0} \mathrm{C}\right)$ for overnight and centrifuged $(12,600 \mathrm{~g} / 20 \mathrm{~min})$. The soluble protein content in the supernatant was determined by the Kjeldahl method (AOAC, 2005). The protein solubility (PS) was estimated from the amount of protein found in the supernatant and the total sample used to prepare the solution following the Equation Number 1.

PS $(\%)=$ (percent of protein in the supernatant/total protein suspended in the solution) $\times 100$... (1)

\subsubsection{Water holding capacity}

The water holding ability of JSPI was determined by the method stated by (Carcea, 1986) with a slight modification. One (1) $\mathrm{g}$ of protein sample was suspended into $10 \mathrm{~mL}$ of distilled water in a $15 \mathrm{~mL}$ graduated conical centrifuge tube. The suspension was stirred evenly and allowed to stand for $1 \mathrm{~h}$ at room temperature $\left(27^{\circ} \mathrm{C}\right)$. It was then centrifuged at $2217 \mathrm{~g}$ for $30 \mathrm{~min}$, and measured the volume of the supernatant. The water-holding capacity was expressed from the amount of water held by 1.0 $\mathrm{g}$ of protein sample.

\subsubsection{Oil holding capacity}

The oil holding capacity of JSPI was determined following a similar method for water holding capacity, where corn oil was used as a suspension medium instead of water.

\subsubsection{Bulk density}

The JSPI powder was put into a $25 \mathrm{~mL}$ measuring cylinder. The initial weight and the initial volume of the sample were recorded. Then 
JSPI was poured into the cylinder properly. The cylinder was tapped frequently during pouring of protein to avoid the void space. Again, the weight and the volume of the sample were recorded. The final weight and the final volume of the sample were recorded from these differences. The bulk density $(\mathrm{g} / \mathrm{mL})$ was calculated as weight of powder ( $\mathrm{g}$ ) divided by powder volume (mL) (Okaka and Potter, 1979) according to Equation Number 2.

Bulk density $(\mathrm{g} / \mathrm{mL})=($ Final weight of sample /Final volume of sample)

\subsubsection{Gelation characteristics}

The gelation capacity of JSPI was determined according to the method followed by (Coffmann and Gracia, 1977) with a slight modification. A range of sample suspensions of 2 to14 percentage $(\mathrm{w} / \mathrm{v})$ was prepared in $5 \mathrm{~mL}$ distilled water and $1.0 \mathrm{M} \mathrm{NaCl}$ solution. The test tubes containing these suspensions were then heated for one $1 \mathrm{~h}$ in a boiling water bath followed by rapid cooling under running cold tap water. The tubes were further cooled for $2 \mathrm{~h}$ at $4{ }^{0} \mathrm{C}$. The least gelation concentration (LGC) was determined as the minimum concentration required to form a self-supporting gel when the sample did not fall or slip from the inverted test tube.

\subsubsection{Measurement of foam properties}

Foaming capacity and stability of JSPI at different $\mathrm{pH}$ (1.5-11.5) were determined according to the method followed by (Aruna and Prakash, 1993). The protein samples (2 g) were taken into $250 \mathrm{~mL}$ beakers and diluted with 100 $\mathrm{mL}$ of distilled water. The $\mathrm{pH}$ values were adjusted from 1.5 to 11.5 by using $\mathrm{HCl}$ and $\mathrm{NaOH}$. The suspensions were mixed thoroughly using magnetic stirrer, and finally, they were homogenized at $300 \mathrm{~g}$ for $5 \mathrm{~min}$ in a homogenizer (WiseMix ${ }^{\mathrm{TM}}$, HG-15 $\mathrm{D}$ ). The volume of the produced foam in each beaker was measured by measuring cylinder within no later than $30 \mathrm{~s}$. The increment of foam volume was estimated following the Equation Number 3 and expressed as percent foam capacity. The decrease of foam volume within $30 \mathrm{~min}$ was measured, and the foam stability was calculated using Equation Number 4.

Foaming capacity $(\%)=($ Foam volume $/$ Initial sample volume) $\times 100$

Foaming stability $(\%)=($ Foam volume after 30 minutes / Initial foam volume) $\times 100$

\subsubsection{Measurement of emulsion properties}

Emulsification capacity of JSPI at different $\mathrm{pH}$ (1.5-11.5) was determined according to the method stated by (Beuchat et al., 1975) and expressed as percent of oil emulsified per $g$ of protein. One (1) $g$ of isolated protein powder was taken in a beaker and mixed with $25 \mathrm{~mL}$ distilled water. After complete dispersion by stirring using a blender at 8,000 rpm, $5 \mathrm{~mL}$ groundnut oil was added and blending was continued until phase separation was seen. The emulsion capacity was estimated based on separated cream following the Equation Number 5. Emulsion stability at different $\mathrm{pH}$ (1.5-11.5) was determined according to the method of (Pearce and Kinsella, 1978). The prepared emulsions were transferred into test tubes and held at $70{ }^{\circ} \mathrm{C}$ in a water bath for $45 \mathrm{~min}$. Then the tubes were allowed to stand at room temperature for $3 \mathrm{~h}$. Percent stability was calculated from the height of the remaining emulsified layer after experimental time to that of the original emulsified layer according to Equation Number 6.

Emulsification capacity $(\%)=($ Cream volume $/$ Initial sample volume $) \times 100$--------- $(5)$

Emulsion stability $(\%)=($ Cream volume after 3 $\mathrm{h} /$ Initial cream volume) $\times 100$------ (6)

\subsubsection{Statistical analysis}

The experiments were carried out in triplicate and the average values are reported in the ensuing sections. The statistical analyses were carried out by using data analysis tools, Microsoft Office Excel 2010. The significance difference between two mean values was determined using one way analysis of variance at $95 \%$ confidence level $(\mathrm{p}<0.05)$. The inbuilt program in Microsoft ExcelTM was used for this purpose. 


\subsection{Secondary structural analysis}

Fourier Transform Infrared (FTIR) spectrophotometer was used in the present study to observe the conformation and secondary structural motifs of the isolated protein. The IR spectra were acquired through Perkin Elmer FTIR (Spectrum-2) instrument operated by CPU32M software. The JSPI powder was scanned within 450 to $4000 \mathrm{~cm}^{-1}$ using a triglycine sulfate (TGS) detector. A total of 8 scans at $4 \mathrm{~cm}^{-1}$ resolution were accumulated at $0.2 \mathrm{~cm} / \mathrm{sec}$ scanning speed. The JFS flour and the separated JFS starch were also scanned to observe the comparative spectra among those materials. The protein sample was diluted in deionized water at $1 \%$ concentration (w/v) for the secondary structural quantification. The spectrum of the aqueous protein solution was acquired in the same IR conditions described above. The blank spectrum of water was subtracted from the protein spectrum. The baseline subtracted protein spectra were analyzed by using Perkin Elmer's proprietary software (Version 10.05.03) and a peak fit software Peak Fit version 4.12 (Sea Solve Software Inc. Framingham, USA). The peak Fit Software was used for quantitative analysis of the secondary structure of the protein. The original spectra (of amide region-I, 1600-1700 $\mathrm{cm}^{-1}$ ) without any smoothing were fitted with Gaussian shape and were analyzed by local least square (LLS) algorithm. Percentage of secondary structures (a-helix, $\beta$-sheets, $\beta$-turns, and random coils) was estimated using Equation Number 7 (Ngarize et al., 2004; Haque et al., 2015).

Secondary structure $(\%)=\mathrm{A}_{\text {ind }} / \mathrm{A}_{\text {total }} \times 100---(7)$
Where, $\mathrm{A}_{\text {ind }}=$ Sum of the area of individual secondary structure within amide I band $\mathrm{A}_{\text {total }}=$ Area of total amide I band

The positions or locations of bands for each secondary structural element ( $\beta$-sheets, $a$-helix, and $\beta$ turns) of tested proteins in $\mathrm{H}_{2} \mathrm{O}$ were considered based on the information available in the literature (Kong and Yu, 2007; Haque et al., 2014). As suggested in Table 1 , the bands from 1620 to $1640 \mathrm{~cm}^{-1}$ and $1674 \mathrm{~cm}^{-1}$ to $1680 \mathrm{~cm}^{-1}$ were assigned to $\beta$-sheets. The bands from 1641 to $1647 \mathrm{~cm}^{-1}$ was assigned to random coil. The bands within 1648 and $1660 \mathrm{~cm}^{-1}$ were assigned to a -helix. Similarly, the bands appearing at and in the vicinity of $1663 \mathrm{~cm}^{-1}, 1671 \mathrm{~cm}^{-1}, 1683 \mathrm{~cm}^{-}$ $1,1688 \mathrm{~cm}^{-1}$ and $1694 \mathrm{~cm}^{-1}$ were assigned to $\beta$ turns. The peaks between $1600 \mathrm{~cm}^{-1}-1619 \mathrm{~cm}^{-1}$ were not considered while quantifying the secondary structural features, as they are known to be generated from aromatic side chains (Ngarize et al., 2004).

\section{Results and Discussion}

\subsection{Protein content}

The protein content in the JSPI was $76.89 \%$. This quantitative value is comparable with other research findings. For example, Sogi et al. (2002) prepared tomato seed protein isolate with $71.32 \%$ protein content whereas crude isolate of rice bran protein contained $60 \%$ protein (Chandi and Sogi, 2007). On the other hand, (Joshi et al., 2011) estimated about $90 \%$ protein in lentil protein isolate. The variation of protein contents in the isolations might be due to the amount of protein fractions in the sources and intracomponents bonds in the sources from where the proteins are isolated.

Table 1. Assigned peak locations for the secondary structural properties of JSPI in amide-I region

\begin{tabular}{ll}
\hline Peak locations & Secondary structural elements \\
\hline$\leq 1619$ & Aromatic side chain \\
$1620-1640$ & $\beta$-sheet (low frequency) \\
$1641-1647$ & Random coil \\
$1648-1660$ & a -helix \\
$1661-1673$ & $\beta$ turn \\
$1674-1680$ & $\beta$-sheet (high frequency) \\
$1681 \geq$ & $\beta$ turn \\
\hline
\end{tabular}




\subsection{Functional properties of JSPI \\ 3.2.1 Protein solubility}

The solubility of JSPI was determined as $58.44 \%$. This value is comparable with percent solubility of rice bran protein concentrate, which ranged from $47.69 \%$ to $73 \%$ based on varieties of rice (Chandi and Sogi, 2007). (Joshi et al., 2011) found the percent solubility of vacuum dried lentil protein isolate was about $51 \%$, although they reported higher solubility when the protein was dried using spray dryer and freeze dryer. Protein isolate with high solubility is preferred for direct consumption as well as utilization as a food ingredient. It is worthy to mention that the JSPI in the current study was prepared by using a vacuum dryer and laboratory grinder. However, the literature suggests that spray dried powder possess more amorphous particles, which provides increased solubility during rehydration (Chiou et al., 2008; Haque et al., 2015). Using of spray dryer for commercial production of JSPI is expected to produce protein isolate with higher solubility.

\subsubsection{Water holding capacity}

Water holding capacity of the JSPI was measured as $2.89 \mathrm{~mL} \mathrm{H}_{2} \mathrm{O} / \mathrm{g}$ protein. High water holding capacity of proteins helps to reduce moisture loss from bakery goods. Also, it is required to maintain freshness and moist mouth feel of baked foods. In comparison, the water holding capacity of JSPI is lower than wheat bran protein, $4.20 \mathrm{~mL} \mathrm{H} \mathrm{H}_{2} \mathrm{O} / \mathrm{g}$ (Idris et al., 2003) but higher than that of cowpea protein $2.20 \mathrm{~mL}$ $\mathrm{H}_{2} \mathrm{O} / \mathrm{g}$ (Ragab et al., 2004). The obtained values indicate that a certain portion of JSPI needs to be supplemented with wheat protein to have adequate swelling and water retention during food preparation.

\subsubsection{Oil holding capacity}

The oil-holding capacity of JSPI was $1.57 \mathrm{~mL}$ oil/g protein, which is slightly lower compared to wheat bran protein $1.70 \mathrm{~mL} / \mathrm{g}$ (Idris et al., 2003). High oil holding capacity is preferred in the formulation of food systems like sausages, cake batters, mayonnaise, and salad dressings. This property of protein also influences the taste of foods.

\subsubsection{Bulk density}

This important parameter signifies the behavior of a product in dry mixes and determines the packaging requirement of a product. The bulk density of JSPI was $0.67 \mathrm{~g} / \mathrm{mL}$. The obtained value is less compared to the bulk density of casein $0.89 \mathrm{~g} / \mathrm{mL}$ (Sogi et al., 2002). Low bulk density is advantageous for the formulation of weaning foods regarding packaging and transportation (Onimawo and Egbekun, 1998).

\subsubsection{Gelation characteristics}

The JSPI did not form a consistent gel in pure water. However, $12 \%$ (w/v) JSPI solution in 1.0 $\mathrm{M} \mathrm{NaCl}$ made a firm gel (Table 2). The current protein isolate showed the lower least gelling concentration (12\%) compared to lentil protein isolate (14\%) (Joshi et al., 2011). They used phosphate buffer at $\mathrm{pH} 7.0$ instead of $\mathrm{NaCl}$. The lower least gelation concentration implies the greater gelling capacity of the protein (Kaur and Singh, 2007).

Table 2. Gelation capacity (GC) of jackfruit seeds protein isolate in water and $\mathrm{NaCl}$ solution

\begin{tabular}{|c|c|c|}
\hline Isolated proteins (\%) & $\mathrm{GC}$ in $\mathrm{H}_{2} \mathrm{O}$ & $\mathrm{GC}$ in $1.0 \mathrm{M} \mathrm{NaCl}$ solution \\
\hline 2 & - & - \\
\hline 4 & - & - \\
\hline 6 & - & + \\
\hline 8 & - & ++ \\
\hline 10 & - & ++ \\
\hline 12 & - & +++ \\
\hline 14 & - & +++ \\
\hline
\end{tabular}

Note: Symbols: - no gel; + weak gel; ++ strong gel; +++ very strong gel 


\subsubsection{Foaming properties}

The foaming capacity (FC) of isolated jackfruit seed protein was found to be $\mathrm{pH}$ dependent. As shown in Fig. 1, the alkaline $\mathrm{pH}$ provided a favorable condition for enhanced foam formation. The lowest FC $(6 \%)$ was found at $\mathrm{pH}$ 5.5 , near the isoelectric point of the protein. JSPI possessed foaming capacity of $42 \%, 25 \%, 46 \%$, $58 \%$, and $74 \%$ respectively, at $\mathrm{pH} 1.5,3.5,7.5$, 9.5, and 11.5. The findings comply with the observations by (N-nadozie et al., 2015) that the alkaline condition of the solution significantly increases the protein solubility and foaming capacity. This trend could be due to the variation of $\mathrm{pH}$ affects the net charge and electrostatic balance of the protein solution. In this way, the solubility of protein tends to be minimum near the isoelectric point where the net charge is zero. The higher FC at $\mathrm{pH} 11.5$ was likely due to the increased net charges on the protein, which weakened the hydrophobic interactions but increased the flexibility of the protein (Idris et al., 2003). These phenomena allowed the protein to diffuse more rapidly to the air-water interface to encapsulate air particles and then enhanced the foam formation.

The foaming stability (FS) requires the formation of a thick, cohesive, and viscoelastic film around each gas bubble (Damodaran, 1990; Halling, 1981). Isolated jackfruit seed protein showed poor foam stability at $\mathrm{pH} 5.5(0.83 \%)$. On either side of $\mathrm{pH} 5.5$, the foaming stability gradually increased and reached its maximum value at $\mathrm{pH}$ $11.5(47 \%)$. About 26\%, $39 \%$, and $21 \%$ FS were observed at $\mathrm{pH} 7.5,9.5$, and 1.5 , respectively (Fig. 1). (Sogi et al., 2002) reported that tomato seed meals had negligible foam stability at $\mathrm{pH}$ 5.0, which improved as the $\mathrm{pH}$ was increased to 7.0. (Meuser et al., 2001) also observed a considerable effect of $\mathrm{pH}$ on the stability of foams. The improvement of FS in the alkaline $\mathrm{pH}$ is likely due to increased solubility and surface activity of the soluble protein.

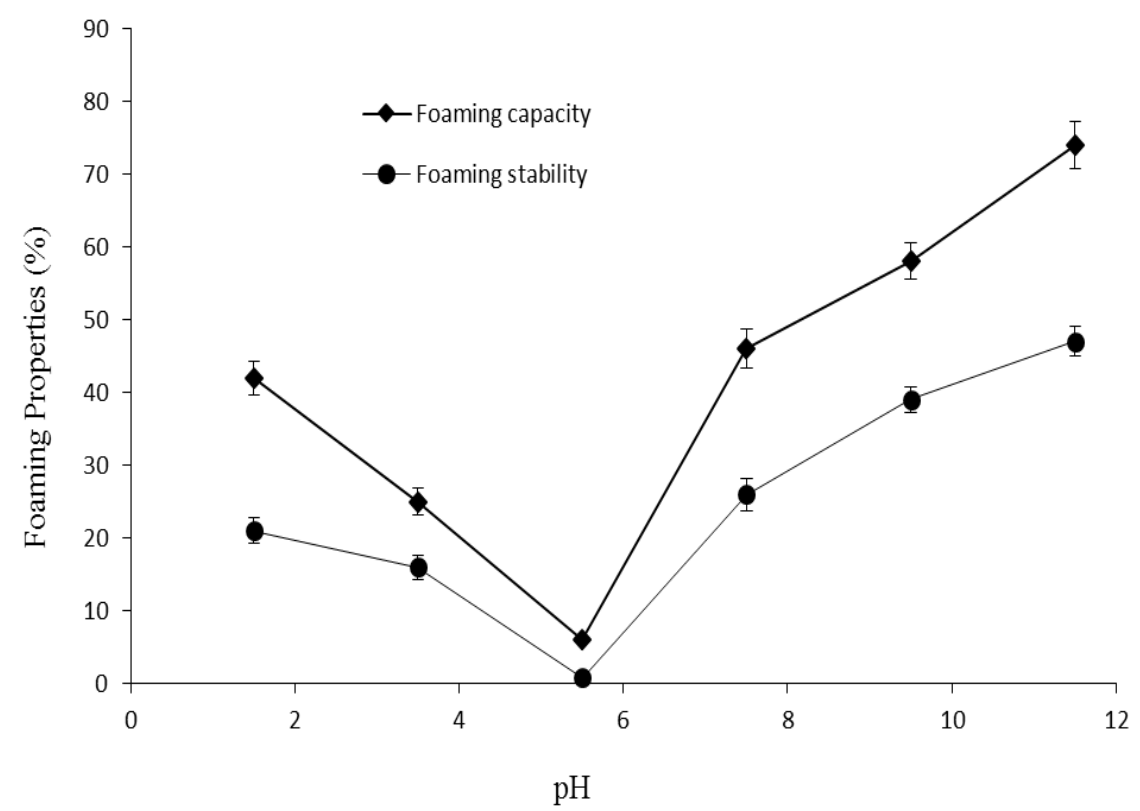

Fig. 1. Effect of $\mathrm{pH}$ on the foaming capacity and foaming stability of jackfruit seeds protein isolate (JSPI) 


\subsubsection{Emulsifying properties}

Like foaming properties, the solution of $\mathrm{pH}$ has a significant effect on emulsion properties ( $\mathrm{p}<0.05)$. As shown in Fig. 2, JSPI had a minimum emulsion capacity (EC) $(2 \%)$ at $\mathrm{pH}$ 5.5 , which increased on either side of this $\mathrm{pH}$. The $\mathrm{pH} 11.5$ of the solution showed the highest EC (63\%), which was followed by the $\mathrm{pH} 9.5$ and 7.5 with EC values of $56 \%$ and $25 \%$, respectively. The observed results suggest that the alkaline $\mathrm{pH}$ improved the emulsion capacity from the acidic one. Dependence of emulsion capacity on $\mathrm{pH}$ was expected, as the emulsion capacity of a protein is known to depend on the hydrophilic-lipophilic balance and electrostatic repulsion at the isoelectric point.

The $\mathrm{pH}$ of the solution affected the emulsion stability (ES) also. JSPI had minimum emulsion stability at $\mathrm{pH} 5.5(0.43 \%$ after $3 \mathrm{~h})$ and reached the maximum value of $52 \%$ at $\mathrm{pH} 11.5$ (Fig. 2). Differences observed might be due to the variations of the hydrophilic-lipophilic balance of the protein along with the $\mathrm{pH}$ gradient. (Hung and Zayas, 1991) suggested that various factors including $\mathrm{pH}$, droplet size, net charge, interfacial tension, viscosity, and protein conformation could affect the values of ES.

\subsection{Conformational properties of jackfruit seed (JFS) flour and JSPI}

The IR spectra presented in Fig. 3 shows that the JFS flour is a mixture of a high amount of starch (band region 900-1200 cm-1) and comparatively low amount of protein (band region 1200-1700 $\mathrm{cm}-1)$. The spectral region for carbohydrate prominently erects by stretching vibration of $\mathrm{C}$ $\mathrm{C}, \mathrm{C}-\mathrm{O}$ bonds and deformation of $\mathrm{C}-\mathrm{O}-\mathrm{H}, \mathrm{C}-\mathrm{O}-\mathrm{C}$ bonds of various oligo- and polysaccharides (Naumann, 2000; Grube et al., 2002). On the other hand, the polypeptide and protein repeat units give the characteristic IR bands through vibration by $\mathrm{C}=\mathrm{O}$ and $\mathrm{C}-\mathrm{N}$ stretching and $\mathrm{N}-\mathrm{H}$ bending stresses (Susi and Byler, 1986; Surewicz and Mantsch, 1988). After isolation of protein, the spectrum of JSPI, in Fig. 4, presented the major amide regions of amide I-III (band region 1200-1700 cm-1).

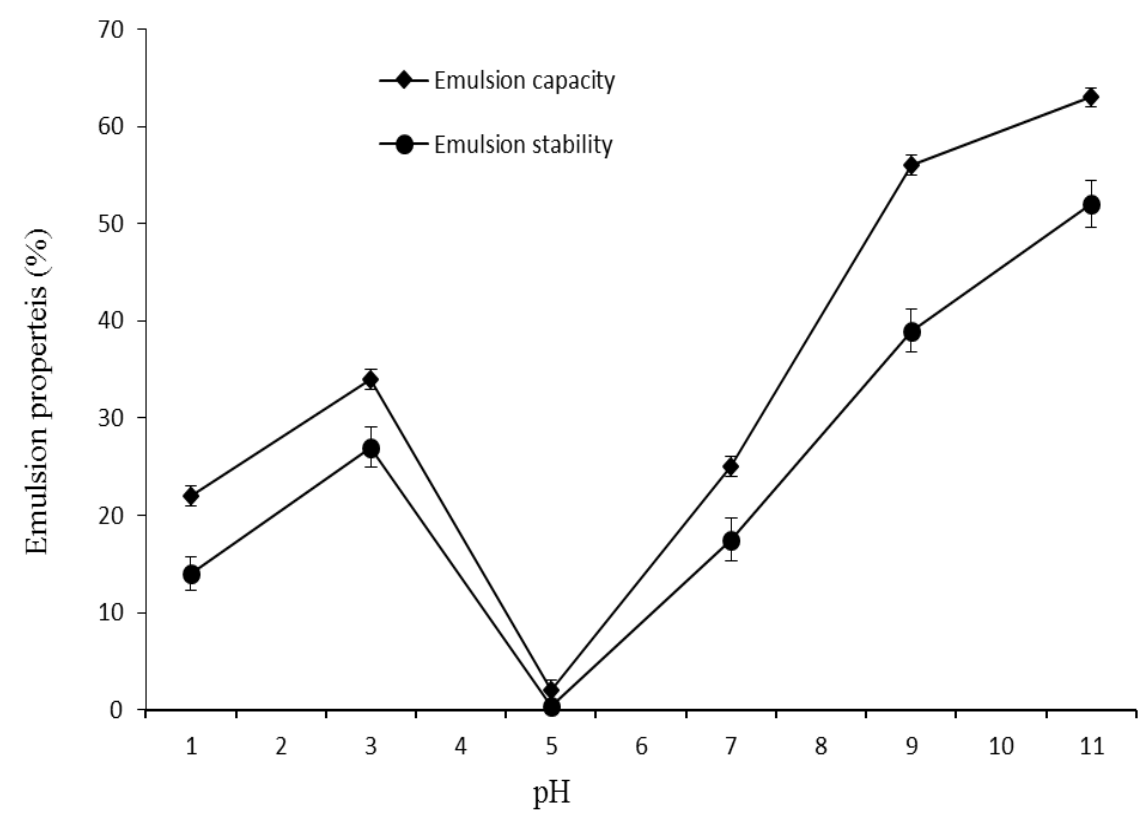

Fig. 2. Effect of $\mathrm{pH}$ on the emulsion capacity and foaming stability of jackfruit seeds protein isolate (JSPI) 


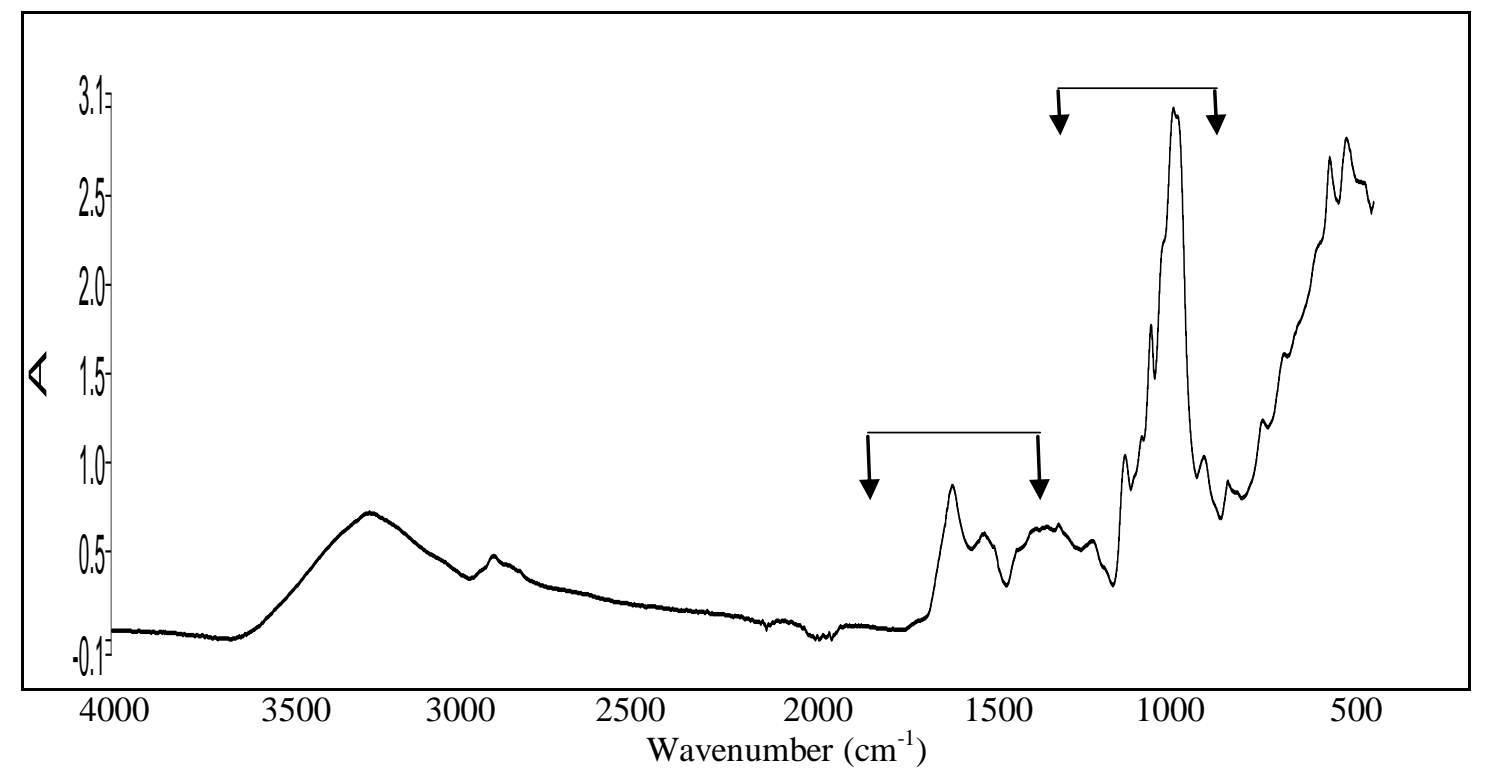

Fig. 3. FTIR absorbance spectra of jackfruit seed flour.

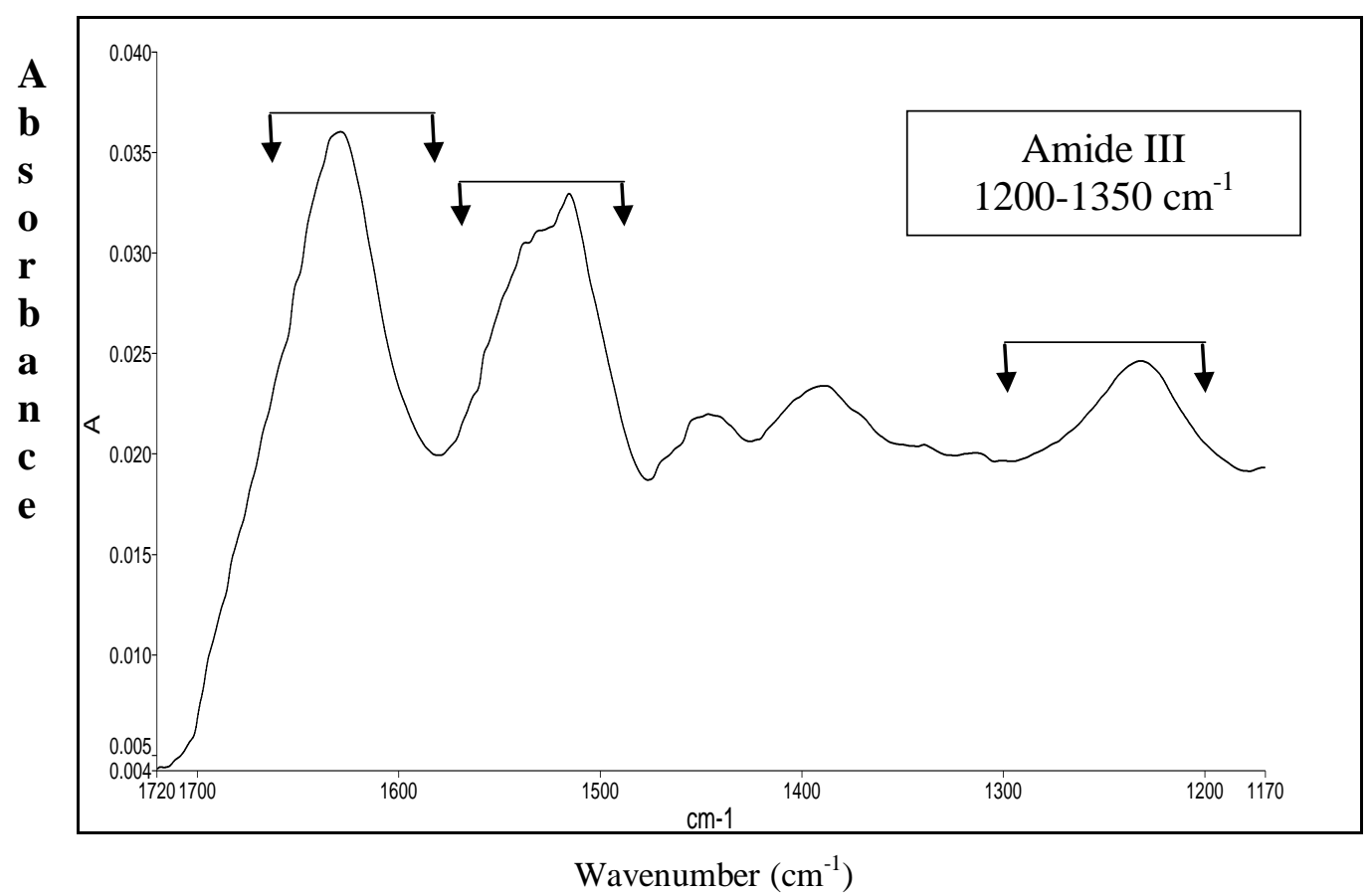

Fig. 4. FTIR spectrums of JFS protein isolate showing the important amide regions 


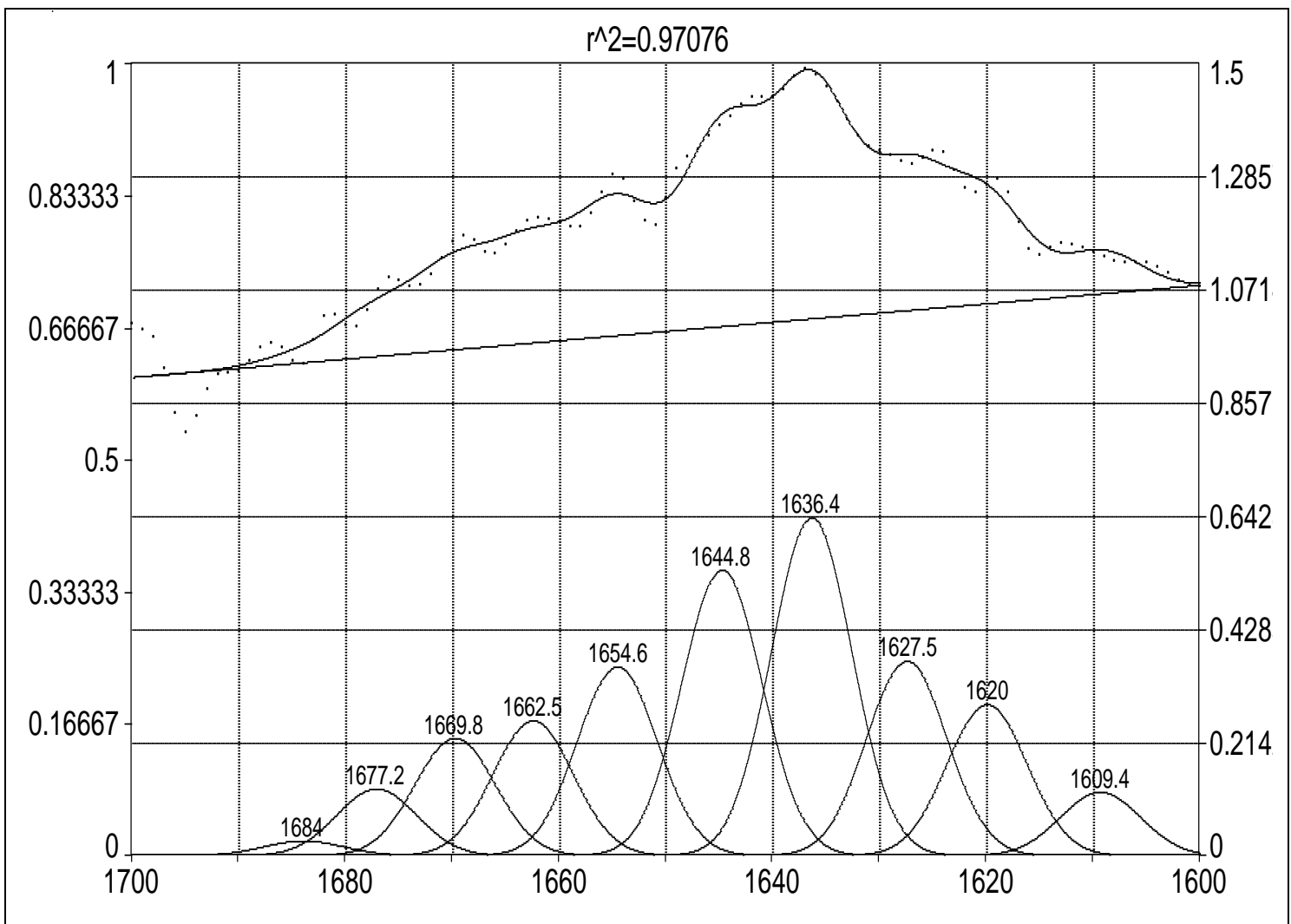

Fig. 5. Fitted spectra of the JFS protein isolate in the amide-I region.

The fitted spectrum for quantification of the secondary structural elements of the protein is presented in Fig. 5. There were nine bands, excluding side chain, produced for the best fitting of the amide-I region (1600-1700 cm-1) with an $r^{2}$ value of 0.97 . The quantification tools of the assigned bands estimated that the JFS protein contained $50.28 \% \beta$-sheet, $21.71 \%$ a helix, $8.86 \% \quad \beta$-turn, and $19.15 \%$ unordered structure. The results indicated that the $\beta$-sheet is the dominant secondary structure of JFS protein.

\section{Conclusions}

The protein fraction of the jackfruit seed was successfully isolated through $\mathrm{pH}$ treatment and centrifugation process. About $77 \%$ proteins were found to be present in the resultant JSPI. It showed acceptable characteristics for the plan of using JSPI in food formulations. For example, the protein possesses attractive foam formation property, good solubility, and gel-forming ability. Variation of $\mathrm{pH}$ in the solution was found to have a significant effect on foaming and emulsion properties. Both the foaming capacity and emulsion capacity reached their maximum values (74\% and $63 \%$, respectively) at the $\mathrm{pH}$ of 11.5. The least gelling concentration of JSPI in $\mathrm{NaCl}$ solution was observed at $12 \%$. Further, the protein isolate possessed adequate water holding capacity, oil holding capacity, and bulk density. The JFS protein contained $50.28 \% \beta$-sheet, $21.71 \%$ a-helix, $8.86 \% \quad \beta$-turn, and $19.15 \%$ unordered properties in the secondary structure. The physicochemical and functional properties of JSPI claim that the jackfruit seed may be a good protein source for the food system. 


\section{Acknowledgments}

The authors gratefully acknowledge the Ministry of Education of Bangladesh for financing the project. The first author also cordially acknowledges the Ministry of Science and Technology, Bangladesh for awarding her NST (National Science and Technology) fellowship for MS study.

\section{References}

AOAC (Association of Official Analytical Chemists). 2005. Official Methods of Analysis $18^{\text {th }}$ Ed. Association of Official Agricultural Chemists, MaryLand, USA.

Aruna V., Prakash V. 1993. Functional properties of the total proteins of sunflower (Helianthus annuus L.) seedseffect of physical and chemical treatments. Journal of Agricultural and Food Chemistry, 41: 18-23.

BBS, 2015. Yearbook of Agricultural Statistics of Bangladesh. Planning Division, Ministry of Planning, Peoples Republic of Bangladesh, Dhaka.

Beuchat LR., Cherry JP., Quinn MR. 1975. Physicochemical properties of peanut flour as affected by proteolysis. Journal of Agricultural and Food Chemistry, 23: 616-620.

Carcea BM. 1986. Functional properties of drum dried chickpea. (Cicer arictinum L). Journal of Food Science, 51: 1518-1526.

Chandi GK., Sogi DS. 2007. Functional properties of rice bran protein concentrate. Journal of Food Engineering, 79: 592597.

Chiou D., Langrish TAG., Braham R. 2008. Partial crystallization behavior during spray drying: simulations and experiments. Drying Technology, 26: 2738.
Coffman C., Gracia VV. 1977. Functional properties and amino acid content of protein isolate from mug bean flour. Journal of Food Technology, 12: 473478.

Damodaran S. 1990. Interfaces, protein films and foams. Advances in. Food and Nutrition. Research, 34: 1-79.

Grube M., Bekers M., Upite D., Kaminska E. 2002. Infrared spectra of some fructans. Spectroscopy, 16: 289-296.

Halling PJ. 1981. Protein-stabilized foams and emulsions. Critical Reviews in Food Science \& Nutrition, 21:155-203.

Haque MA., Aldred P., Chen J., Adhikari B. 2015. Drying and denaturation characteristics of whey protein isolate in the presence of lactose and trehalose. Food Chemistry, 177: 8-16.

Haque MA., Aldred P., Chen J., Barrow C., Adhikari B. 2014. Drying and denaturation characteristics of $a$ lactalbumin, $\beta$-lactoglobulin and bovine serum albumin in a convective drying process. Journal of Agricultural and Food Chemistry, 62 (20): 4695-4706.

Hasan SMK., Hossain MA., Hossain MJ., Roy SM., Sarker MSH. 2010. Preparation of biscuit from jackfruit (Artocarpus heterophyllus) seed flour blended with wheat flour. The Agriculturists, 8(1): 1018.

Houde M., Khodaei N., Benkerroum N., Karboune S. 2018. Barley protein concentrates: Extraction, structural and functional properties. Food Chemistry, 254: 367-376.

Hung SC., Zayas JF. 1991. Emulsifying capacity and emulsion stability of milk proteins and corn germ protein flour. Journal of Food Science, 56: 1216-1223.

Idris WH., Babiker EE., Tinay AHE. 2003. Fractionation, solubility and functional 
properties of wheat bran proteins as influenced by $\mathrm{pH}$ and/or salt concentration. Nahrung/Food, 47 (6): 425-429.

Ji Y-Y., Li Y-Q. 2010. The role of secondary structure in protein structure selection. The European Physical Journal E, 32(1): 103-107.

Joshi M., Adhikari B., Aldred P., Panozzo JF., Kasapis S. 2011. Physicochemical and functional properties of lentil protein isolates prepared by different drying methods. Food Chemistry, 129: 15131522.

Kaur M., Singh N. 2007. Characterization of protein isolates from different Indian chickpea (Cicer arietinum L.) cultivars. Food Chemistry, 102: 366-374.

Kaushik P., Dowling K., McKnight S., Barrow C., Wang B., Adhikari B. 2016. Preparation, characterization and functional properties of flaxseed protein isolate. Food Chemistry, 197: 212-220.

Kinsella JE. 1979. Functional properties of soy proteins. Journal of the American Oil Chemists Society, 56: 242-249.

Kong J., Yu S. 2007. Fourier transforms infrared spectroscopic analysis of protein secondary structures. Acta Biochimica et Biophysica Sinica, 39: 549-559.

Mcwatters KH., Cherry JP. 1977. Emulsification, foaming and protein solubility properties of defatted soybean, peanut, field pea and pecan flours. Journal of food science, 42 (6): 1444-1447.

Meuser F., Busch KG., Fuhrmeister H., Rubach K. 2001. Foam forming capacity of substances present in rye. Cereal Chemistry, 78: 50-54.

Naumann D. 2000. FT-Infrared and FT-Raman spectroscopy in biomedical research, in: Infrared and Raman Spectroscopy of Biological Materials, H.U. Gremlich and
B. Yan, eds, Marcel Dekker, Inc., NY, Basel, 323-377 pp.

Ngarize S., Herman H., Adams A., Howell N. 2004. Comparison of changes in the secondary structure of unheated, heated, and high-pressure-treated $\beta$-lactoglobulin and ovalbumin proteins using Fourier transform Raman spectroscopy and selfdeconvolution. Journal of Agricultural and Food Chemistry, 52: 6470-6477.

N-nadozie EF., Kelechi AJ., Deborah O. 2015. Effects $\mathrm{pH}$ and $\mathrm{NaCl}$ on the Protein Solubility, Emulsifying and Foaming Properties of Germinated and Ungerminated Melon (Colocynthis citrullus) Seeds Flour. International Journal of Nutrition and Food Sciences, 4(2): 173-177.

Ocloo FCK., Bansa D., Boatin R., Adom T., Agbemavor WS. 2010. Physico-chemical, functional and pasting characteristics of flour produced from jackfruits (Artocarpus heterophyllus Lam.) seeds. Agriculture and Biology Journal of North America, 1(5): 903-908.

Okaka JC., Potter NN. 1979. Physicochemical and functional properties of cowpea powders processed to reduce beany flavour. Journal of Food Science, 44: 1235-1240.

Onimawo IA., Egbekun NM. 1998. Comprehensive food science and nutrition. Ambik Publishers, Benin City. 103-220 pp.

Pasiakos SM., Agarwal S., Leiberman HR., Fulgoni VL. 2015. Sources and Amounts of Animal, Dairy, and Plant Protein Intake of US Adults in 2007-2010. Nutrients, 7(8): 7058-7069.

Pearce KN., Kinsella JE. 1978. Emulsifying properties of proteins: evaluation of a turbidimetric technique. Journal of Agricultural and Food Chemistry, 26: 716-723. 
Ragab DM., Babiker EE., Eltinay AH. 2004. Fractionation, solubility and functional properties of cowpea (Vigna unguiculata) proteins as affected by $\mathrm{pH}$ and/or salt concentration. Journal of Food Chemistry, 84(2): 207-212.

Reis MFT., Renata CFB., Rita de CSS., Cristiane MV., Rafael CIF., Olga RG. 2016. Optimization of protein extraction process from jackfruit seed flour by reverse micelle system. Acta Scientiarum, 38 (3): 283-290.

Sogi DS., Garg SK., Bawa AS. 2002. Functional properties of seeds meals and protein concentrates from tomato processing waste. Journal of Food Science, 67: 2997-3001.

Surewicz WK., Mantsch HH. 1988. New insight into protein secondary structure from resolution-enhanced infrared spectra. Biochim Biophys Acta, 952: 115-130.
Susi H., Byler DM. 1986. Resolution-enhanced Fourier transform infrared spectroscopy of enzymes. Methods Enzymol, 130: 290311.

Ulloa JA., Barbosa MCV., Vaxquez JAR., Ulloa PR., Ramirez JCR., Carillo YS., Torres LG. 2017. Production, physico-chemical and functional characterization of a protein isolate from jackfruit (Artocarpus heterophyllus) seeds. cyTA- Journal of Food, 15(4): 497-507.

Wang M., Hettiarachchy NS., Qi M., Burks W., Siebenmorgen T. 1999. Preparation and Functional Properties of Rice Bran Protein Isolate. Journal of Agricultural and Food Chemistry, 47: 411-416.

Zayas JF., Lin CS. 1989. Emulsifying Properties of Corn Germ Proteins. Cereal Chemistry, 66(4): 263-267. 